\title{
The effect of atorvastatin on sexual function and depressive symptoms in young women with elevated cholesterol levels - a pilot study
}

Wpływ atorwastatyny na funkcjonowanie seksualne i objawy depresyjne u młodych kobiet z podwyższonym stężeniem cholesterolu — badanie pilotażowe

\author{
Robert Krysiak', Agnieszka Drosdzol-Cop², Violetta Skrzypulec-Plinta², Bogusław Okopien \\ ${ }^{1}$ Department of Internal Medicine and Clinical Pharmacology, Medical University of Silesia, Katowice, Poland \\ ${ }^{2}$ Chair of Woman's Health, School of Health Sciences in Katowice, Medical University of Silesia, Katowice, Poland
}

\begin{abstract}
Introduction: Statins were found to improve erectile function in men. No previous study has prospectively investigated sexual functioning in women receiving these agents.

The aim of this study was to evaluate the impact of atorvastatin therapy on female sexual function, and depressive symptoms in young women with elevated cholesterol levels.

Material and methods: The study included 14 women with elevated cholesterol levels and 14 matched women with normal plasma lipids. Hypercholesterolaemic women were then treated with atorvastatin ( $20-40 \mathrm{mg}$ daily) for 24 weeks. Apart from measuring plasma lipids, at the beginning and at the end of the study, all participants of the study completed questionnaires evaluating sexual function (Female Sexual Function Index - FSFI) and the presence and severity of depressive symptoms (Beck Depression Inventory-Second Edition - BDI-II). Results: The mean total FSFI score was insignificantly lower, while the BDI-II score was higher in women with hypercholesterolaemia than in the control group. Both groups significantly differed in domain scores for arousal and orgasm. Atorvastatin decreased the domain score for desire, increased the domain score for orgasm, but did not affect the total FSFI score and the remaining domain scores. Moreover, atorvastatin tended to reduce the BDI-II score. Treatment-induced changes in desire, orgasm, and the BDI-II did not correlate with the effect of atorvastatin on plasma lipids.

Conclusions: Atorvastatin treatment produces a relatively mild effect on sexual functioning and mood in women, affecting only selected elements of female sexual behaviour. (Endokrynol Pol 2018; 69 (6): 688-694)
\end{abstract}

Key words: depressive symptoms; hypercholesterolaemia; sexual functioning; statins

\begin{abstract}
Streszczenie
Wstęp: Wykazano korzystny wpływ statyn na poprawę erekcji u mężczyzn. W żadnych poprzednich badaniach nie oceniano prospektywnie funkcjonowania seksualnego kobiet otrzymujących te leki. Badanie miało na celu ocenę wpływu terapii atorwastatyną na funkcje seksualne i objawy depresyjne u młodych kobiet z podwyższonym stężeniem cholesterolu.

Materiał i metody: Badaniem objęto 14 kobiet z podwyższonym stężeniem cholesterolu i 14 dopasowanych kobiet z prawidłowymi stężeniami lipidów w osoczu. Kobiety z hipercholesterolemią były następnie leczone atorwastatyną (20-40 mg/d.) przez 24 tygodnie. Poza oceną stężenia lipidów, na początku i końcu badania, wszystkie uczestniczki wypełniały kwestionariusze oceniające funkcje seksualne (Indeks Funkcji Seksualnych Kobiet - FSFI) oraz obecność i nasilenie objawów depresyjnych (Beck Depression Inventory-Second Edition - BDI-II). Wyniki: Średnia całkowita punktacja skali FSFI była nieznamiennie niższa, natomiast wyniki skali BDI-II wyższe u kobiet z hipercholesterolemią w porównaniu z grupą kontrolną. Obie grupy różniły się istotnie pod względem domen pobudzenia seksualnego i orgazmu. Terapia atorwastatyną zmniejszyła punktację domeny pożądania seksualnego, zwiększyła domenę orgazmu, ale nie wpłynęła na całkowity wynik FSFI i pozostałe domeny skali. Ponadto terapia atorwastatyną powodowała redukcję punktacji skali BDI-II. Wywołane leczeniem zmiany w pożądaniu seksualnym, orgazmie i wynikach BDI-II nie korelowały z wpływem atorwastatyny na stężenie lipidów w osoczu. Wnioski: Leczenie atorwastatyną powoduje względnie łagodny wpływ na funkcjonowanie seksualne i nastrój u kobiet, oddziałując tylko na wybrane elementy zachowań seksualnych. (Endokrynol Pol 2018; 69 (6): 688-694)
\end{abstract}

Słowa kluczowe: objawy depresyjne; hipercholesterolemia; funkcjonowanie seksualne; statyny

\section{Introduction}

Coronary heart disease is the main cause of cardiovascular morbidity and mortality in women [1]. The number of women living with and dying of coronary heart disease and stroke, as well as the number of hospital discharges because of heart failure or stroke, are higher in women than in men [2]. 3-hydroxy-3-methyl-glutaryl-CoA (HMC-CoA) reductase inhibitors (statins) are considered the first-line treatment for 
patients with coronary heart disease and hypercholesterolaemia. The benefits of statin therapy in cardiovascular diseases go beyond their lipid-lowering properties. HMC-CoA reductase inhibitors are known to exert nonlipid-related (so-called "pleiotropic") effects, which include regulation of the growth and migration of smooth muscle cells, improvement of the functioning of vascular endothelium, as well as the inhibitory effect on coagulation, fibrinolysis, and platelet activities [3-5].

In men, erectile dysfunction may be considered as a predictor of cardiovascular disease in future or as a marker of silent atherosclerotic cardiovascular disease $[6,7]$. A meta-analysis of 11 randomised trials [8], as well as a meta-analysis of five randomised trials [9], showed that HMG-CoA reductase inhibitors cause a clinically relevant improvement of erectile function as measured by the five-item version of the International Inventory of Erectile Function. In another meta-analysis, although there was no significant difference in erectile function between statins and placebo, compared with placebo plus sildenafil, HMC-CoA reductase inhibitors plus sildenafil clearly improved erectile function [10]. Finally, the beneficial effect of statin therapy on erectile functioning was more prominent in patients with elevated cholesterol levels, but less pronounced than that of tadalafil [11].

On the other hand, a decrease in androgen biosynthesis may have an unfavourable effect on sexual functioning. The results of both a meta-analysis by Schooling et al. [12] and one By our research group [13] indicate that statins may decrease plasma testosterone levels in men, probably because of their inhibitory action on production of the substrate for the local synthesis of androgens in adrenal cortex and gonads [14]. A decrease in testosterone, dehydroepiandrosterone sulphate (DHEA-S), and androstenedione was also found in women with elevated androgen levels as a consequence of either polycystic ovary syndrome [15-18] or non-classic congenital adrenal hyperplasia $[19,20]$. Low testosterone was found to be negatively associated with libido, arousal, and masturbation frequency, while low DHEA-S is associated with desire and masturbation frequency [21]. Taking these results into account, statins may have an unfavourable effect on desire, and maybe also on other aspects of female sexual functioning.

In the only study conducted to date, statin therapy was not associated with menstrual and menopausal disorders, infertility, and ovarian/sexual dysfunction [22]. However, unlike in men, to the best of our knowledge, no previous study has investigated the impact of statins on female sexual functioning in women in detail. Therefore, the aim of this study was to evaluate the impact of atorvastatin therapy on female sexual functions and depressive symptoms in young women with elevated cholesterol levels.

\section{Material and methods}

\section{Study population}

The study population consisted of 14 women (20-45 years old) with hypercholesterolaemia, who had been complying with lifestyle intervention for at least 12 weeks before the beginning of the study. To be included, they had to meet the following criteria of hypercholesterolaemia: total cholesterol above $200 \mathrm{mg} / \mathrm{dL}$ and LDL-cholesterol more than $130 \mathrm{mg} / \mathrm{dL}$. The exclusion criteria were as follows: any other acute or chronic disorders, a history of urogynaecological operations that might affect sexual function, pregnancy, or lactation. We also excluded sexually inactive women and individuals treated pharmacologically. The study protocol was accepted by the local Ethics Committee and all participants of the study signed an informed consent form.

\section{Methods}

The enrolled women were treated with atorvastatin (20 mg daily), administered once daily at bedtime. If after six weeks LDL cholesterol levels were still above $130 \mathrm{mg} / \mathrm{mL}$, the daily dose of atorvastatin was increased to $40 \mathrm{mg}$. The investigation of possible drug-induced side-effects was performed fortnightly. Atorvastatin-treated women were compared with the control group including 14 age- and weight-matched healthy normolipidemic women with a family history of early-onset coronary heart disease, following lifestyle modification for more than three months. During the entire study, both groups of patients continued to comply with the lifestyle modification.

Laboratory assays were performed at the beginning of the study and 24 weeks later. Blood samples were taken between 8 and 9 a.m. after an overnight 12 -h fasting, and all assays were performed in duplicate to minimise analytical errors. Plasma levels of total cholesterol, LDL cholesterol, HDL cholesterol, and triglycerides were assayed by routine laboratory techniques (Roche Diagnostics, Basel, Switzerland). LDL-cholesterol levels were measured directly.

After collecting blood samples, the participants were asked to complete three questionnaires. The first questionnaire assessed demographic characteristics, smoking, physical activity, education, occupation, stress exposure, general health, the number of sexual partners, as well as the number and duration of marriages, deliveries, and abortions. The second questionnaire (Female Sexual Function Index - FSFI) evaluated female sexual functioning, while the third one (Beck 
Table I. Sociodemographic characteristics and plasma lipids in the study population

Tabela I. Charakterystyka socjodemograficzna i lipidy osocza w populacji badanej

\begin{tabular}{|c|c|c|}
\hline & Hypercholesterolaemia & Control subjects \\
\hline Number of patients & 14 & 14 \\
\hline Age [years; mean (SD)] & $34(6)$ & $35(5)$ \\
\hline Body mass index $\left[\mathrm{kg} / \mathrm{m}^{2} ;\right.$ mean (SD)] & $26.3(4.0)$ & $25.9(3.7)$ \\
\hline $\begin{array}{l}\text { Smokers (\%)/Number of cigarettes a day [n; mean (SD)]/Duration of smoking } \\
\text { [months, mean (SD)] }\end{array}$ & $36 / 11(6) / 104(41)$ & $29 / 10(6) / 98(35)$ \\
\hline Physical activity: total/once a week/several times a week/once a month [\%] & $86 / 36 / 36 / 14$ & $86 / 29 / 43 / 14$ \\
\hline Primary or vocational/secondary/university education [\%] & $21 / 29 / 50$ & $21 / 36 / 43$ \\
\hline Occupational activity/Blue-collar/white-collar/pink-collar workers [\%] & $79 / 14 / 29 / 36$ & $79 / 21 / 29 / 29$ \\
\hline Stress exposure $(\%)$ & 86 & 86 \\
\hline Number of sexual partners [n; mean (SD)] & $2.1(1.0)$ & $2.2(1.3)$ \\
\hline Number of marriages [n; mean (SD)]/Duration of marriages [months; mean (SD)] & $1.2(0.6) / 81(32)$ & $1.3(0.6) / 88(30)$ \\
\hline Number of deliveries [n; mean (SD)]/Number of abortions [n; mean (SD)] & $2.0(0.8) / 0.5(0.6)$ & $1.8(0.7) / 0.4(0.5)$ \\
\hline Systolic blood pressure [mmHg; mean (SD)] & $130(11)$ & $126(14)$ \\
\hline Diastolic blood pressure [mmHg; mean (SD)] & $81(7)$ & $79(7)$ \\
\hline Total cholesterol [mg/dL; mean (SD)] & $265(31)^{\mathrm{a}}$ & $199(28)$ \\
\hline LDL cholesterol [mg/dL; mean (SD)] & $175(23)^{\mathrm{a}}$ & $105(12)$ \\
\hline HDL cholesterol [mg/dL; mean (SD)] & $58(7)$ & $62(8)$ \\
\hline Triglycerides [mg/dL; mean (SD)] & $135(30)$ & $141(29)$ \\
\hline
\end{tabular}

ap $<0.001$ vs. control group, SD — standard deviation

Depression Inventory-Second Edition - BDI-II) assessed depressive symptoms.

FSFI consists of 19 questions assessing six dimensions of female sexual function: sexual desire, arousal, lubrication, orgasm, satisfaction, and coital pain in the past four weeks $[22,23]$. Answers are rated from 0 to 5 (arousal, lubrication, orgasm, and dyspareunia) or from 1 to 5 (desire and sexual satisfaction). 0 means no sexual activity in the previous four weeks. The minimum score for sexual desire and satisfaction is greater than 0 because their assessment does not require the presence of sexual activity. The total FSFI score, obtained from the sum of the items in each domain multiplied by the domain factor ( 0.6 for desire, 0.3 for arousal and lubrication, and 0.4 for orgasm, satisfaction, and pain), ranges from 2 to 36 (higher scores are suggestive of better sexual function). A total score of less than 26.55 is assumed to indicate sexual dysfunction $[23,24]$.

BDI-II is a self-rating scale with 21 items, which are focused on depression symptoms: affective, motivational, cognitive, and physiological during the preceding two weeks [25]. The items reflect diagnostic criteria for depressive disorders outlined in the Diagnostic and Statistical Manual of Mental Disorders, Fourth Edition [26]. Each item is scored on a four-point Likert scale from 0 to 3 . The total BDI-II score, being the sum of the item scores, ranges from 0 to 63 . The BDI-II score from 14 to 19 points is interpreted as mild depression, $20-28$ as moderate depression, and 29-63 as severe depression [25].

\section{Statistical analysis}

Quantitative data were natural-log transformed to meet the assumptions of normality and equal variance. Comparisons between both groups were made by the $t$-test for independent samples with the multiple testing correction of Benjamini and Hochberg false discovery rate. Student's paired $t$-test was used to compare pre- and post-treatment data within the same group. Categorical variables were analysed by $\chi^{2}$ test. Pearson's $r$-tests were used to test correlations. Statistical significance was assumed at $\mathrm{p}<0.05$.

\section{Results}

\section{General characteristics of the study groups}

There were no differences between the study groups in age, body mass index, smoking, education, physical activity, occupational activity, type of work, stress exposure, the number of sexual partners, the number and duration of marriages, the number of deliveries and abortions, as well as in systolic and diastolic blood pressure (Table I). As expected, total and LDL cholesterol levels were higher in women with hypercholesterolaemia than in control subjects (Table I). 
Table II. Sexual function in young women with and without hypercholesterolaemia

Tabela II.Funkcjonowanieseksualnemłodych kobietzhipercholesterolemiq i bez niej

\begin{tabular}{lcc}
\hline Variable & Atorvastatin & Control group \\
\hline FSFI score [mean (SD)] & & \\
\hline At the beginning of the study & $31.19(3.10)$ & $32.72(3.02)$ \\
At the end of the study & $30.57(3.25)$ & $32.27(3.65)$ \\
\hline FSFI score $\leq \mathbf{2 6 . 5 5 ( \% )}$ & & \\
\hline At the beginning of the study & 29 & 14 \\
At the end of the study & $36^{\mathrm{a}}$ & 14 \\
\hline Sexual desire [mean (SD)] & & \\
\hline At the beginning of the study & $5.44(0.44)$ & $5.57(0.44)$ \\
At the end of the study & $4.88(0.56)^{\mathrm{b}, \mathrm{c}}$ & $5.53(0.58)$ \\
\hline Sexual arousal [mean (SD)] & & \\
\hline At the beginning of the study & $4.99(0.48)^{\mathrm{b}}$ & $5.55(0.44)$ \\
At the end of the study & $4.95(0.43)^{\mathrm{b}}$ & $5.51(0.42)$ \\
\hline Lubrication [mean (SD)] & & \\
\hline At the beginning of the study & $5.34(0.51)$ & $5.37(0.49)$ \\
At the end of the study & $5.11(0.36)$ & $5.20(0.54)$ \\
\hline Orgasm [mean (SD)] & & \\
\hline At the beginning of the study & $4.91(0.57)^{\mathrm{a}}$ & $5.49(0.46)$ \\
At the end of the study & $5.46(0.53)^{\mathrm{c}}$ & $5.43(0.46)$ \\
\hline Sexual satisfaction [mean (SD)] & & \\
\hline At the beginning of the study & $5.31(0.43)$ & $5.40(0.49)$ \\
At the end of the study & $5.14(0.44)$ & $5.37(0.38)$ \\
\hline Dyspareunia [mean (SD)] & & \\
\hline At the beginning of the study & $5.20(0.42)$ & $5.34(0.40)$ \\
At the end of the study & $5.03(0.38)$ & $5.23(0.43)$ \\
\hline
\end{tabular}

${ }^{a} p<0.05,{ }^{b} p<0.01 v s$. control group; ${ }^{c} p<0.05 v s$. baseline value; $\mathrm{SD}$ - standard deviation

Neither adverse effects nor complications were observed in atorvastatin-treated patients and women with normal plasma lipids, and all participants completed the study. Atorvastatin reduced total cholesterol by $25 \%$ ( $p<0.001)$ and LDL cholesterol by 38\% ( $<<0.001)$. No changes in plasma lipids were observed in the control group. At the end the study, there were no differences between the groups in plasma lipid levels (data not shown).

\section{Assessment of sexual function}

The mean total FSFI score was insignificantly lower $(\mathrm{p}=0.095)$ in women with hypercholesterolaemia than in the control group (Table II). Both groups significantly differed in domain scores for arousal and orgasm, but not for desire, lubrication, satisfaction, and pain (Figure 1). There were no differences in the total FSFI score and all domain scores between the beginning and the end
Table III. Depressive symptoms in young women with and without hypercholesterolaemia

Tabela III. Objawy depresyjne u młodych kobiet z hipercholesterolemia i bez niej

\begin{tabular}{lcc}
\hline Variable & Atorvastatin & Control group \\
\hline BDI-Il score [mean (SD)] & & \\
\hline At the beginning of the study & $11.6(3.7)^{\mathrm{a}}$ & $7.6(3.9)$ \\
At the end of the study & $9.4(3.0)$ & $8.0(4.3)$ \\
\hline Depressive symptoms [n (\%)] & & \\
\hline At the beginning of the study & $4(29)$ & $2(14)$ \\
At the end of the study & $3(21)$ & $2(14)$ \\
\hline Mild symptoms [n (\%)] & & \\
\hline At the beginning of the study & $3(21)$ & $2(14)$ \\
At the end of the study & $2(14)$ & $2(14)$ \\
\hline Moderate symptoms [n (\%)] & & $0(0)$ \\
\hline At the beginning of the study & $1(7)$ & $0(0)$ \\
At the end of the study & $1(7)$ & \\
\hline Severe symptoms [n (\%)] & & $0(0)$ \\
\hline At the beginning of the study & $0(0)$ & $0(0)$ \\
At the end of the study & $0(0)$ &
\end{tabular}

ap $<0.05$ vs. control group; SD — standard deviation

of the study in the control group. Atorvastatin decreased the domain score for desire and increased the domain score for orgasm. The drug did not affect the total FSFI score and the remaining domain scores, and it did not have a significant effect on the percentage of patients with sexual dysfunction. At the end of the study, both groups differed in desire, arousal, and the number of women with sexual dysfunction (Figure 2). The total FSFI score was insignificantly higher $(p=0.086)$ in women receiving atorvastatin than in the control group (Table II).

\section{Assessment of depressive symptoms}

The mean total BDI-II score was higher in women with elevated cholesterol levels than in the control group (Table III). There were no differences between the study groups in the percentages of women with total, mild, moderate, and severe depressive symptoms. Atorvastatin tended to decrease the BDI-II score $(p=0.083)$, while no changes were found in untreated individuals with normal plasma lipids. At the end of the study, the BDI-II score, as well as the number of patients with total, mild, moderate, and severe depressive symptoms did not differ between the study groups.

At baseline, in both study groups, the total BDI-II score inversely correlated with the total FSFI score [women with hypercholesterolaemia: $\mathrm{r}=-0.41$ ( $p<0.001)$; women with normal plasma lipids: $r=-0.34$ $(\mathrm{p}<0.01)$ ] and body mass index [women with hyper- 


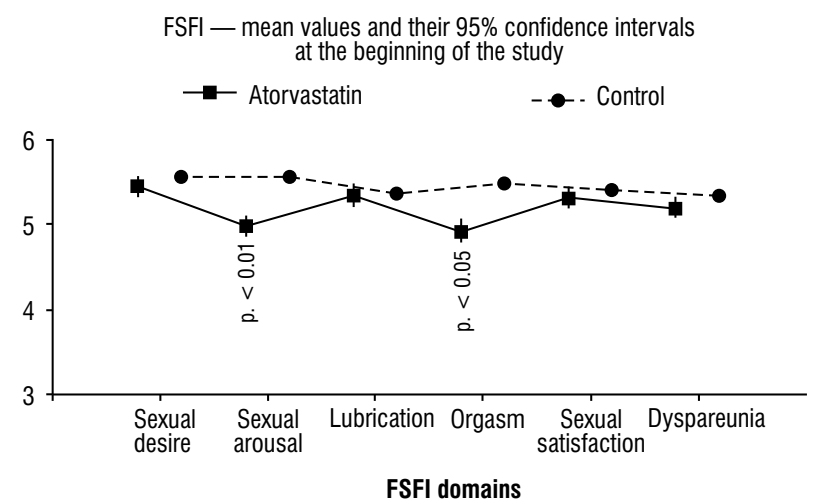

Figure 1. FSFI domains in young women with and without hypercholesterolaemia - at the beginning of the study

Rycina 1. Domeny skali FSFI u młodych kobiet $z$ hipercholesterolemia i bez niej - na początku badania

cholesterolaemia: $r=-0.46(p<0.001)$; women with normal plasma lipids: $r=-0.42(p<0.001)]$. In women with hypercholesterolaemia the total FSFI score inversely correlated with total cholesterol $[\mathrm{r}=-0.31(\mathrm{p}<0.05)]$ and LDL cholesterol $[\mathrm{r}=-0.37(\mathrm{p}<0.01)]$. In this group of women, there were inverse correlations between LDL cholesterol and domain scores for arousal $[\mathrm{r}=-0.39$ $(p<0.001)]$ and orgasm $[r=0.37(p<0.01)]$. The effect of atorvastatin on plasma cholesterol weakly correlated with its action on desire $[r=-0.26(p<0.05)$ for total cholesterol; $r=-0.31(p<0.05)$ for LDL cholesterol] but did not correlate with its action on the total and domain scores of FSFI, the BDI-II score, and on the percentage of women with total, mild, moderate, and severe depressive symptoms.

\section{Discussion}

Our study is the first to show that statin therapy exhibits a relatively weak effect on sexual functioning in women with elevated LDL cholesterol levels. Despite a neutral effect on the total FSFI score, the treatment affected sexual functioning in two domains. A positive impact on orgasm was counterbalanced by a negative action on sexual desire. The obtained results indicate that statin therapy may bring benefits to women with orgasmic disturbances, but it may be, at least potentially, harmful in women with hypoactive sexual desire disorder.

Sexual functioning was slightly disturbed in women with hypercholesterolaemia compared with healthy subjects. This sexual dysfunction was limited to arousal and orgasm, and only functioning in these domains correlated with total and LDL cholesterol. Strict inclusion criteria and the similar clinical and laboratory characteristics of both study groups minimised the possibility that these differences resulted from the impact of other



Figure 2. FSFI domains in young women with and without hypercholesterolaemia - at the end of the study

Rycina 2. Domeny skali FSFI u młodych kobiet z hipercholesterolemia i bez niej - na końcu badania

concurrent diseases or concomitant therapies. The obtained results suggest that arousal and orgasm are more susceptible to unfavourable changes in plasma lipids than other aspects of female sexual functioning. Moreover, it may be assumed that women with coexisting changes in arousal and orgasm should be screened for the presence of elevated cholesterol levels.

In our study, the effect of atorvastatin on sexual desire weakly correlated with statin-induced changes in total and LDL cholesterol, while no association was found between the effect of this agent on plasma lipids and orgasm. This finding suggests that a reduction in plasma lipids plays a small role in the effects of HMG-CoA reductase inhibitors on sexual functioning. These effects may be secondary to diminished post-translational protein prenylation, which is an important process regulating many cellular processes, including cellular signalling, differentiation and growth regulation, and membrane transport [27].

Unfavourable changes in desire contrasted with a neutral effect of hypercholesterolaemia on this aspect of female sexual functioning. The main source of cholesterol contained in steroid hormones are LDLs [14], and therefore in patients with very low LDL cholesterol levels steroidogenesis may be impaired [13]. Interestingly, in a subgroup of women aged 25-44 years, with no use of systemic hormonal contraception, being a population very similar to our group of patients, sexual desire correlated with circulating levels of total testosterone, free testosterone, androstenedione, and DHEA-S [28]. It should be underlined that in most patients participating in the study by Wåhlin-Jacobsen et al. [28], androgen levels were within the reference range. This observation suggests that even small differences in steroid hormone levels may be associated with a risk of hypoactive sexual desire disorder. The 
inhibitory effect HMG-CoA reductase inhibitors on the proliferation of theca-interstitial cells resulted in a decrease in LH-stimulated production of testosterone and progesterone $[29,30]$, and this effect may explain why the correlation between the improvement in desire and the reduction in LDL cholesterol levels was weak.

It is difficult explain why statins improved orgasmic reaction. This effect cannot be explained by treatment-induced changes in serum androgen levels, because in numerous studies HMG-CoA reductase inhibitors were found to reduce circulating levels of testosterone and DHEA-S, irrespective of the underlying disorder [15-20]. Therefore, much more convincing is its association with pleiotropic effects of statins, affecting blood flow to the structures involved in sexual activities. Interestingly, statins were found to increase nitric oxide bioavailability [31]. Alternatively, an increase in a domain score for orgasm may be secondary to a neurogenic regulation of sexual functioning. In line with this hypothesis, statins reduced severity, symptoms, and nerve conduction parameters in diabetic polyneuropathy, and these effects seem to be related to reductions in lipid peroxidation and oxidative stress [32, 33].

Although the total BDI-II score weakly correlated with the total FSFI score at entry, the effect of atorvastatin on depressive symptoms did not correlate with its action of sexual functioning. The obtained results suggest that either discrete disturbances in sexual functioning contribute to mood disturbances or impaired arousal and orgasm are a consequence of reduced mood. Apart from a possible impact of sexual dysfunction, the higher BDI-II score may be explained by other mechanisms, such as reduced serotonin receptor sensitivity or transporter activity [34]. On the other hand, a small improvement in depressive symptoms cannot be explained by the effect of atorvastatin on sexual functioning. A much more likely explanation is its association with statin-induced changes in the content of glucocorticoids, serotonin, or dopamine in the limbic system, which is line with the results of other authors [35, 36].

The present study has some limitations. The main limitation was its small sample size, as well as the fact that the study was non-randomised and non-placebo controlled. Moreover, FSFI and BDI-II scoring systems, being self-report inventories, are subjective in nature. Because atorvastatin in our study was administered at moderate doses, it cannot be excluded that the effect of statin therapy would be stronger if the drug were administered at higher doses. We excluded women diagnosed with cardiovascular disease, and it is possible that the effect of statin therapy in women with a history of acute coronary syndrome or stroke may differ from that observed in our group of patients. Additionally, the effect on sexual functioning and depressive symptoms does not have to represent a class effect of statins and may be unique to atorvastatin.

\section{Conclusions}

In conclusion, our study has shown for the first time that relatively mild abnormalities of lipid metabolism are associated with disturbances in female sexual functioning and mood. The effect of atorvastatin on sexual functioning was domain-dependent, only partially beneficial, and did not contribute to its action on depressive symptoms. Further studies with larger groups of patients are required to confirm our results.

\section{Author disclosure statement}

No competing financial interests exist. The authors report no financial, personal, political, intellectual, or religious conflicts of interest. The authors alone are responsible for the content and writing of the paper.

\section{Contribution to authorship}

Robert Krysiak - conception and design, analysis of data, interpretation of data, drafting the article, data collection, paper preparation.

Agnieszka Drosdzol-Cop - conception and design, revising it critically for important intellectual content, final approval of the version to be published.

Violetta Skrzypulec-Plinta - final approval of the version to be published.

Bogusław Okopien - final approval of the version to be published.

\section{References}

1. Mosca L, Barrett-Connor E, Wenger NK. Sex/gender difference in cardiovascular disease prevention: what a difference a decade makes. Circulation. 2011; 124(19): 2145-2154, doi: 10.1161/CIRCULATIONAHA.110.968792, indexed in Pubmed: 22064958.

2. Roger VL, Go AS, Lloyd-Jones DM, et al. American Heart Association Statistics Committee and Stroke Statistics Subcommittee, American Heart Association Statistics Committee and Stroke Statistics Subcommittee. Heart disease and stroke statistics - 2011 update: a report from the American Heart Association. Circulation. 2011; 123(4) e18-e209, doi: 10.1161/CIR.0b013e3182009701, indexed in Pubmed: 21160056.

3. Babelova A, Sedding DG, Brandes RP. Anti-atherosclerotic mechanisms of statin therapy. Curr Opin Pharmacol. 2013; 13(2): 260-264, doi: 10.1016/j.coph.2013.01.004, indexed in Pubmed: 23402735.

4. Blum A, Shamburek R. The pleiotropic effects of statins on endothelia function, vascular inflammation, immunomodulation and thrombogenesis. Atherosclerosis. 2009; 203(2): 325-330, doi: 10.1016/j.atherosclerosis.2008.08.022, indexed in Pubmed: 18834985.

5. Krysiak R, Okopień B, Herman Z. Effects of HMG-CoA reductase inhibitors on coagulation and fibrinolysis processes. Drugs. 2003; 63(17): 1821-1854, indexed in Pubmed: 12921488.

6. Fung MM, Bettencourt R, Barrett-Connor E. Heart disease risk factors predict erectile dysfunction 25 years later: the Rancho Bernardo Study. J Am Coll Cardiol. 2004; 43(8): 1405-1411, doi: 10.1016/j.jacc.2003.11.041, indexed in Pubmed: 15093875.

7. Tikkanen MJ, Jackson G, Tammela T, et al. Erectile dysfunction as a risk factor for coronary heart disease: implications for prevention. Int J Clin Pract. 2007; 61(2): 265-268, doi: 10.1111/j.1742-1241.2006.01271.x, indexed in Pubmed: 17263713. 
8. Kostis JB, Dobrzynski JM. The effect of statins on erectile dysfunction: a meta-analysis of randomized trials. J Sex Med. 2014; 11(7): 1626-1635, doi: 10.1111/jsm.12521, indexed in Pubmed: 24684744.

9. Cai $\mathrm{X}$, Tian $\mathrm{Ye}, \mathrm{Wu}$, et al. The role of statins in erectile dysfunction: a systematic review and meta-analysis. Asian J Androl. 2014; 16(3): 461-466, doi: 10.4103/1008-682X.123678, indexed in Pubmed: 24556747.

10. Cui $\mathrm{Y}$, Zong $\mathrm{H}$, Yan $\mathrm{H}$, et al. The effect of statins on erectile dysfunction: a systematic review and meta-analysis. J Sex Med. 2014; 11(6): 1367-1375, doi: 10.1111/jsm.12497, indexed in Pubmed: 24628781.

11. Gokce Mİ, Gülpınar Ö, Öztürk E, et al. Effect of atorvastatin on erectile functions in comparison with regular tadalafil use. A prospective single-blind study. Int Urol Nephrol. 2012; 44(3): 683-687, doi: 10.1007/s11255-012-0126-z, indexed in Pubmed: 22252217.

12. Schooling CM, Au Yeung SL, Freeman G, et al. The effect of statins on testosterone in men and women, a systematic review and meta-analysis of randomized controlled trials. BMC Med. 2013; 11: 57, doi: 10.1186/1741-7015-11-57, indexed in Pubmed: 23448151.

13. Krysiak R, Kowalska B, Żmuda W, et al. The effect of aggressive rosuvastatin treatment on steroid hormone production in men with coronary artery disease. Basic Clin Pharmacol Toxicol. 2014; 114(4): 330-335, doi: 10.1111/bcpt.12169, indexed in Pubmed: 24330280

14. Miller W. Steroidogenic Enzymes. Endocr Dev. 2008: 1-18, doi: $10.1159 / 000134751$.

15. Banaszewska B, Pawelczyk L, Spaczynski RZ, et al. Effects of simvastatin and metformin on polycystic ovary syndrome after six months of treatment. J Clin Endocrinol Metab. 2011; 96(11): 3493-3501, doi: 10.1210/jc.2011-0501, indexed in Pubmed: 21865358.

16. Celik O, Acbay O. Effects of metformin plus rosuvastatin on hyperandrogenism in polycystic ovary syndrome patients with hyperlipidemia and impaired glucose tolerance. J Endocrinol Invest. 2012; 35(10): 905-910, doi: 10.3275/8371, indexed in Pubmed: 22522778.

17. Raja-Khan N, Kunselman AR, Hogeman CS, et al. Effects of atorvastatin on vascular function, inflammation, and androgens in women with polycystic ovary syndrome: a double-blind, randomized, placebo-controlled trial. Fertil Steril. 2011; 95(5): 1849-1852, doi: 10.1016/j. fertnstert.2010.11.040, indexed in Pubmed: 21144505.

18. Gao L, Zhao FL, Li SC. Statin is a reasonable treatment option for patients with Polycystic Ovary Syndrome: a meta-analysis of randomized controlled trials. Exp Clin Endocrinol Diabetes. 2012; 120(6): 367-375, doi: 10.1055/s-0032-1304619, indexed in Pubmed: 22639397.

19. Krysiak R, Okopien B. The effect of metformin on androgen production in diabetic women with non-classic congenital adrenal hyperplasia. Exp Clin Endocrinol Diabetes. 2014; 122(10): 568-571, doi: 10.1055/s-0034-1382048, indexed in Pubmed: 25054311.

20. Krysiak R, Kowalcze K, Bednarska-Czerwińska A, et al. The Effect of Simvastatin on Plasma Steroid Hormone Levels in Metformin-Treated Women with Non-Classic Congenital Adrenal Hyperplasia. Exp Clin Endocrinol Diabetes. 2016; 124(4): 215-219, doi: 10.1055/s-0035-1569375, indexed in Pubmed: 26824284

21. Davis SR, Wahlin-Jacobsen S. Testosterone in women - the clinical significance. Lancet Diabetes Endocrinol. 2015; 3(12): 980-992, doi: 10.1016/S2213-8587(15)00284-3, indexed in Pubmed: 26358173.
22. Ali SK, Reveles KR, Davis $R$, et al. The association of statin use and gonado-sexual function in women: a retrospective cohort analysis. J Sex Med. 2015; 12(1): 83-92, doi: 10.1111/jsm.12736, indexed in Pubmed: 25382624.

23. Rosen R, Brown C, Heiman J, et al. The Female Sexual Function Index (FSFI): a multidimensional self-report instrument for the assessment of female sexual function. J Sex Marital Ther. 2000; 26(2): 191-208, doi: 10.1080/009262300278597, indexed in Pubmed: 10782451.

24. Wiegel M, Meston C, Rosen R. The female sexual function index (FSFI): cross-validation and development of clinical cutoff scores. J Sex Marital Ther. 2005; 31(1): 1-20, doi: 10.1080/00926230590475206, indexed in Pubmed: 15841702

25. Beck AT, Steer RA, Brown GK. BDI-II: Beck Depression Inventory Manual. 2nd ed. Psychological Corporation, San Antonio 1996.

26. American Psychiatric Association. Diagnostic and statistical manual of mental disorders - DSM-IV-TR. 4th ed. American Psychiatric Publishing, Washington 1994.

27. Jasińska M, Owczarek J, Orszulak-Michalak D. Statins: a new insight into their mechanisms of action and consequent pleiotropic effects. Pharmacol Rep. 2007; 59(5): 483-499, indexed in Pubmed: 18048949

28. Wåhlin-Jacobsen S, Pedersen AT, Kristensen E, et al. Is there a correlation between androgens and sexual desire in women? J Sex Med. 2015; 12(2): 358-373, doi: 10.1111/jsm.12774, indexed in Pubmed: 25475395.

29. Izquierdo D, Foyouzi N, Kwintkiewicz J, et al. Mevastatin inhibits ovarian theca-interstitial cell proliferation and steroidogenesis. Fertil Steril. 2004; 82 Suppl 3: 1193-1197, doi: 10.1016/j.fertnstert.2004.03.037, indexed in Pubmed: 15474095

30. Kodaman PH, Duleba AJ. HMG-CoA reductase inhibitors: do they have potential in the treatment of polycystic ovary syndrome? Drugs. 2008; 68(13): 1771-1785, indexed in Pubmed: 18729532.

31. Jacobson JR. Statins in endothelial signaling and activation. Antioxid Redox Signal. 2009; 11(4): 811-821, doi: 10.1089/ars.2008.2284, indexed in Pubmed: 18808324

32. Hernández-Ojeda J, Román-Pintos LM, Rodríguez-Carrízalez AD, et al. Effect of rosuvastatin on diabetic polyneuropathy: a randomized, double-blind, placebo-controlled Phase IIa study. Diabetes Metab Syndr Obes. 2014; 7: 401-407, doi: 10.2147/DMSO.S65500, indexed in Pubmed: 25214797.

33. Leis AA, Stokic DS, Olivier J. Statins and polyneuropathy: setting the record straight. Muscle Nerve. 2005; 32(4): 428-430, doi: 10.1002/mus.20413, indexed in Pubmed: 16094656.

34. Papakostas GI, Ongür D, Iosifescu DV, et al. Cholesterol in mood and anxiety disorders: review of the literature and new hypotheses. Eur Neuropsychopharmacol. 2004; 14(2): 135-142, doi: 10.1016/S0924-977X(03)00099-3, indexed in Pubmed: 15013029.

35. ElBatsh MM. Antidepressant-like effect of simvastatin in diabetic rats. Can J Physiol Pharmacol. 2015; 93(8): 649-656, doi: 10.1139/cjpp-2014-0560, indexed in Pubmed: 26120891.

36. Ormiston T, Wolkowitz OM, Reus VI, et al. Hormonal changes with cholesterol reduction: a double-blind pilot study. J Clin Pharm Ther. 2004; 29(1): 71-73, indexed in Pubmed: 14748901. 